\title{
Simultaneous Determination Of Hyoscine Butyl Bromide and Dipyrone in Their Binary Mixture By RP-HPLC Method.
}

\author{
Nouruddin w. Ali ${ }^{1}$, Mohammed Gamal ${ }^{2}$, Mohammed Abdelkawy ${ }^{3}$ \\ ${ }^{1,2}$ Pharmaceutical Analytical Chemistry Department, Faculty of Pharmacy, Beni-Suef University, Alshaheed \\ Shehata Ahmed Hegazy St., 62574 Beni-Suef Egypt \\ ${ }^{3}$ Pharmaceutical Analytical Chemistry Department, Faculty of Pharmacy, Cairo University, Kasr El-Aini St., \\ 11562, Cairo, Egypt
}

\begin{abstract}
RP-HPLC chromatographic method was developed for determination of Hyoscine Butyl Bromide $(H B B)$ and Dipyrone (DIP). In this method, HBB and DIP were separated by using $C 18(25 \mathrm{~cm} \times 4.6 \mathrm{~mm}$ i.d. $5 \mu \mathrm{m}$ particle size) column as a stationary phase and using water: methanol (50:50) $\mathrm{v} / \mathrm{v} \mathrm{pH}$ adjusted to 7.0 with triflouroacetic acid and triethylamine) as a mobile phase, maintaining the flow rate at $1.0 \mathrm{~mL} \mathrm{~min}{ }^{-1}$ with UV detection at $210 \mathrm{~nm}$. The proposed method was successfully applied for determination of HBB and DIP in pure form and in their pharmaceutical formulations.
\end{abstract}

Keywords: RP-HPL, Chromatography, Hyoscine Butyl Bromide, Dipyrone

\section{Introduction}

Hyoscine butyl bromide is a quaternary ammonium anticholinergic agent. It has antispasmodic action on the smooth muscles of the gastrointestinal, biliary, and urinary tracts [1].

Dipyrone is pyrazolone derivative with a strong analgesic, antipyretic, very weak antiinflammatory effect and spasmolytic activity [1]. The structural formulas of HBB and DIP are shown in Figure 1.

There are many reports for the determination of HBB and DIP either separately or in combination with other drugs including spectrophotometric methods [2-6], chromatographic methods [7-9], electrochemical methods [10-13], Capillary electrophoresis methods [14,15] and titrimetric method [16-18].

Few methods have been mentioned for analysis of HBB and DIP in binary mixture. Erk and Onur [19] developed two spectrophotometric methods for the simultaneous determination of DIP and HBB in their binary mixture. The first method depend on derivative spectrophotometry, the determination of these drugs were performed by measuring the $\mathrm{dA} / \mathrm{d} \lambda$ values at $291.8 \mathrm{~nm}$ and 219.8 $\mathrm{nm}$ in the first derivative spectra of the mixture for DIP and HBB respectively. In the second method, the determination of these compounds in mixture was realized by precipitating HBB with ammonium reineckate at $\mathrm{pH} 6.0$ selectively and reading the absorbance of the solution of the precipitate in acetone at $532.2 \mathrm{~nm}$ for HBB and by measuring the $\mathrm{dA} / \mathrm{d} \lambda$ values at $306.2 \mathrm{~nm}$ in the first derivative spectra of the remaining solution for DIP.

Up to our knowledge, no chromatographic methods have been published for determination of HBB and DIP mixture.

Therefore, the objective of this work is to develop sensitive, selective and reproducible RPHPLC method for simultaneous determination of HBB and DIP for routine quality control analysis of these drugs either in bulk powder or in pharmaceutical formulations. Chromatographic methods are well known for providing high selectivity and sensitivity when used for determination of pharmaceutical drugs.

\section{II.1. Apparatus}

\section{Experimental}

1-Shimadzu Class - LC 10 AD Liquid Chromatography supplied with Shimadzu SPD - 10 A UV - VIS Detector (Shimadzu Corporation,Japan).Phenomenex C18 (25 cm x $4.6 \mathrm{~mm}$ i.d, $5 \mu \mathrm{m}$ particle size) column was used as a stationary phase for HPLC determinations (USA).

2-Sonix TV ss-series ultrasonicator (USA). 


\section{II.2. Materials \\ II.2.1. Pure samples}

Dipyrone (DIP) and hyoscine $\mathrm{N}$ butyl bromide (HBB) were kindly supplied by CID Co. Chemical Industries Development, Giza, Egypt. Their purity was found to be 100.22 \pm 0.544 and $99.21 \pm 1.012$, respectively, according to the company analysis certificate (HPLC).

\section{II.2.2. Market samples}

1- Buscopan compositum ${ }^{\circledR}$ tablets (Batch No 115815T) labeled to contain $250 \mathrm{mg}$ of (DIP) and $10 \mathrm{mg}$ of (HBB), CID Co. Chemical Industries Development, Giza, Egypt.

2-Buscopan compositum ${ }^{\circledR}$ ampoules (Batch No 116551A), each $5 \mathrm{~mL}$ ampoule labeled to contain $2500 \mathrm{mg}$ of (DIP) and $20 \mathrm{mg}$ of (HBB), CID Co. Chemical Industries Development, Giza, Egypt.

\section{II.2.3. Reagents}

All reagents and chemicals used were of analytical grade and were used without further purification

1- Methanol HPLC grade and triethylamine (Sigma Aldrich, Germany).

2-Deionised water (SEDICO pharmaceutical Co., $6^{\text {th }}$ October City, Egypt).

3-Orthophosphoric acid and glacial acetic acid from (EL - NASR Pharmaceutical Chemicals Co., Abu - Zabaal, Cairo, Egypt).

4- Trifluoroacetic acid from Spectrochem, India.

\section{II.3. Preparation of standard solutions}

A-Dipyrone (DIP) and Hyoscine N butyl bromide (HBB) stock standard solutions $\left(1 \mathrm{mg} . \mathrm{mL}^{-1}\right)$.

Weigh accurately 0.1 gram of each drug into a two separate $100-\mathrm{mL}$ volumetric flask, $50 \mathrm{~mL}$ methanol was added, shake to dissolve then complete the volume to the mark with methanol.

B- Dipyrone (DIP) and Hyoscine N butyl bromide (HBB) working standard solutions (100 $\mu \mathrm{g} \cdot \mathrm{mL}^{-1}$ )

Transfer accurately $10 \mathrm{~mL}$ of the stock solution of each drug into two separate $100-\mathrm{mL}$ volumetric flasks and complete to volume with methanol to get $100 \mu \mathrm{g} . \mathrm{mL}^{-1}$ working solution for each drug.

\section{II.4. Procedures}

\section{II.4.1. Linearity and construction of calibration curves:}

Transfer accurate aliquots equivalent to $(20-500) \mu \mathrm{g}$ of HBB and $(50$ - 1200) $\mu \mathrm{g}$ of DIP from their corresponding working solutions $\left(100 \mu \mathrm{g} \cdot \mathrm{mL}^{-1}\right)$ or stock solutions $\left(1000 \mu \mathrm{g} \cdot \mathrm{mL}^{-1}\right)$ into two separate sets of a series of $10-\mathrm{mL}$ volumetric flasks. Complete the volume with methanol. Make triplicate $20 \mu \mathrm{L}$ injections for each concentration. The separation was done on a $\mathrm{C}_{18}$ column using (water: methanol 50: $50 \mathrm{v} / \mathrm{v}, \mathrm{pH}$ adjusted to 7.0 with triflouroacetic acid and triethylamine ) as a mobile phase. All solvents were filtered through a $0.45 \mu \mathrm{m}$ membrane filters before use and degassed in an ultrasonic bath for 20 min. Record the chromatograms at ambient temperature maintaining the flow rate at $1.0 \mathrm{~mL} \cdot \mathrm{min}^{-1}$ and detect the effluent at $210 \mathrm{~nm}$.

Construct the calibration curves for each compound by plotting the peak area/ $10^{4}$ versus the corresponding concentration and then compute the regression equations.

\section{II.4.2. Analysis of laboratory prepared mixtures:}

Prepare mixtures containing HBB and DIP in different ratios. Proceed as mentioned under linearity and construction of calibration curves. Calculate the concentrations of the two compounds from their corresponding regression equations.

\section{II.4.3. Application of the proposed methods to pharmaceutical formulations.}

A) For tablet dosage form

The contents of ten tablets of Buscopan compositum ${ }^{\circledR}$ were thoroughly powdered and mixed then an amount of the powder equivalent to $250 \mathrm{mg}$ of DIP and $10 \mathrm{mg}$ of HBB was weighed accurately in $250-\mathrm{mL}$ beaker, $70 \mathrm{~mL}$ of methanol was added, stirred for about $30 \mathrm{~min}$ then filtered through filter paper into a $100-\mathrm{mL}$ volumetric flask, the beaker and the funnel were washed and the volume was completed with methanol to get a concentration of 2.5 and $0.10 \mathrm{mg} \cdot \mathrm{mL}^{-1}$ for DIP and HBB, respectively. Appropriate dilutions were made to bring up a concentration of 50.0 and $2.0 \mu \mathrm{g} . \mathrm{mL}^{-1}$ for DIP and HBB, respectively and a concentration of 5.0 and 0.2 $\mu \mathrm{g} . \mathrm{mL}^{-1}$ DIP and HBB, respectively. The proposed method was applied for the analysis and calculation of HBB and DIP concentrations.

B) For ampoules dosage form

The contents of five ampoules of Buscopan compositum ${ }^{\circledR}$ were thoroughly mixed then volume of $1 \mathrm{~mL}$ of solution equivalent to $500 \mathrm{mg}$ of DIP and $4 \mathrm{mg}$ of HBB was accurately transferred into a 100 -mL volumetric flask and the volume was completed to the mark with methanol to get a concentration of 5.0 and $0.04 \mathrm{mg} \cdot \mathrm{mL}^{-1}$ 
for DIP and HBB, respectively. Appropriate dilutions were made to bring up a concentration of 250.0 and 2.0 $\mu \mathrm{g} . \mathrm{mL}^{-1}$ for DIP and HBB, respectively and a concentration of 5.0 and $0.04 \mu \mathrm{g} \cdot \mathrm{mL}^{-1}$ DIP and HBB, respectively. The proposed method was applied for the analysis and calculation of HBB and DIP concentrations.

\section{III.1. Method development and optimization}

\section{Results and discussion}

The aim of this work is to develop a method that can be applied successfully for separation and quantification of the studied drugs.

To optimize the RP-HPLC method, it was necessary to test the effect of different variables:

\section{a-The choice of the stationary phase}

The reversed-phase separation was preferred to the normal phase due to the drawbacks of the normalphase mode, for example, hydration of the silica with water, which cause peak tailing .C18 column found was to be more efficient than $\mathrm{C} 8$ column.

\section{b-The choice of the mobile phase}

Mobile phase systems of different compositions and ratios were tried e.g. (water : methanol) using different acids $\left(\mathrm{H}_{3} \mathrm{PO}_{4}, \mathrm{CH}_{3} \mathrm{COOH}\right.$ and $\left.\mathrm{CF}_{3} \mathrm{COOH}\right)$ at different $\mathrm{pH}$ values. Complete separation of $\mathrm{HBB}$ and DIP without interference within a suitable time was achieved using water: methanol (50:50, v/v pH adjusted to 7.0 with $\mathrm{CF}_{3} \mathrm{COOH}$ acid and triethylamine). This selected mobile phase allows the determination of $\mathrm{HBB}$ and DIP in combination without interference and within a suitable time.

\section{c-The effect of $\mathrm{pH}$}

Forked peak of HBB at basic medium was a problem. While forked peak of DIP was appeared at acidic medium. Adjustment of $\mathrm{pH}$ to inhibit this was tried using different acids and bases like glacial acetic acid, triflouroacetic acid, orthophosphoric acid, sodium hydroxide and triethylamine. Forked peak could be overcome by adjusting the $\mathrm{pH}$ at $7.0 \pm 0.02$. In addition, the effect of acid type was studied by using acids of different $\mathrm{pk}_{\mathrm{a}}$ values $\left(\mathrm{H}_{3} \mathrm{PO}_{4}, \mathrm{CF}_{3} \mathrm{COOH}\right.$ and $\left.\mathrm{CH}_{3} \mathrm{COOH}\right)$. It was found that $\mathrm{CF}_{3} \mathrm{COOH}$ acid was necessary for proper peak shape of HBB. Furthermore, the effect of base type was studied by using bases of different $\mathrm{pk}_{\mathrm{b}}$ values $(\mathrm{NaOH}$ and triethylamine). It was found that triethylamine was necessary for proper peak shape of DIP.

\section{d-Flow rate and the scanning wavelength}

Different flow rates were tried of which $1.0 \mathrm{~mL} \cdot \mathrm{min}^{-1}$ proved to be of choice providing good separation within 9 minutes.

The two drugs under investigation were dissolved in methanol separately and examined by the spectrophotometer. it was found that detection at $210 \mathrm{~nm}$ gave good sensitivity for both compounds.

Finally, a satisfactory separation was obtained by using $\mathrm{C} 18(25 \mathrm{~cm} \times 4.6 \mathrm{~mm}$ i.d. $5 \mu \mathrm{m}$ particle size $)$ column as a stationary phase and using water: methanol (50:50) v/v pH adjusted to 7.0 with $\mathrm{CF}_{3} \mathrm{COOH}$ acid and triethylamine ) as a mobile phase, maintaining the flow rate at $1.0 \mathrm{~mL} \mathrm{~min}^{-1}$ with $\mathrm{UV}$ detection at $210 \mathrm{~nm}$. The retention times for HBB and DIP were 3.57 and 8.68 min respectively, Figure 2.

\section{III.2. Method validation}

Method validation was performed according to ICH guidelines ${ }^{(20)}$.

Linearity of the proposed methods was evaluated and it was evident in the concentration range of 2.0-50.0 $\mu \mathrm{g} . \mathrm{mL}^{-1}$ for HBB and 5.0-120.0 $\mu \mathrm{g} \cdot \mathrm{mL}^{-1}$ for DIP, Figures (3-4). Good linearity was evident by the high value of the correlation coefficient and the low intercept value, (Table 4).

The regression equations were calculated and found to be:

$$
\begin{array}{rlrl}
Y 1 & =3.522 C 1+45.92 & r l & =0.9997 \\
Y 2 & =5.326 C 2-63.28 & r 2 & =0.9996
\end{array}
$$

Where $\mathrm{Y} 1$ and $\mathrm{Y} 2$ are the peak area $/ 100, \mathrm{C} 1$ and $\mathrm{C} 2$ are $\mathrm{HBB}$ and DIP concentrations in $\mu \mathrm{g} \cdot \mathrm{mL}^{-1}$ respectively and $\mathrm{r} 1$ and $\mathrm{r} 2$ are the correlation coefficients.

Precision of the proposed RP-HPLC method was evident as shown in Table (4).

Accuracy of the proposed method was checked by applying the proposed method for determination of different blind samples of HBB and DIP. The concentrations were calculated from the corresponding regression equations. The results obtained as shown in Table (1-2).

Accuracy of the method was assured by applying the standard addition technique on Buscopan compositium $^{\circledR}$ tablets and Buscopan compositium ${ }^{\circledR}$ ampoules where good recoveries were obtained as shown in Table (3) revealing no interference from excipients and good accuracy of the proposed method. 
Specificity of the proposed method is evident from the RP-HPLC chromatogram as shown in Figure (2). Robustness of the proposed method was evaluated in the development phase by making small changes in the composition of mobile phase and detection wavelength. The low value of \%RSD shows that the methods are robust and that deliberate small changes in the studied factors did not lead to a significant change in retention values, area or symmetry of the peaks.

System suitability tests are based on the concept that the equipment, electronics, analytical operations and samples constitute an integral system that can be evaluated as whole. System suitability is used to ensure system performance before or during the analysis of the drugs. System suitability was checked by calculating the capacity factor $\left(\mathrm{K}^{\prime}\right)$, tailing factor(T), column efficiency $(\mathrm{N})$, the selectivity factor $(\gamma)$ and resolution(Rs), where the system was found to be suitable as shown in Table (5).

\section{Conclusion}

The proposed method are efficient for providing sensitive, accurate and reproducible quantitative analysis for simultaneous determination of HBB and DIP in bulk powder and in pharmaceutical formulations, without any interference from excipients. RP-HPLC method has the advantages of short analysis time and the availability of the device in every quality control unit so it is suitable for routine analysis.

Statistical analysis was performed by comparing the results of the proposed method with those of manufacturer method. No significant difference was observed regarding accuracy and precision, as shown in Table (6).

The suggested method provides selective, accurate and sensitive analytical procedures for the determination of HBB and DIP. It is suitable for routine analysis and quality control of HBB and DIP in its pharmaceutical formulations.

A<smiles>CCCC[N+]1(C)C2CC(OC(=O)[C@H](CO)c3ccccc3)CC1C1OC12</smiles>

B<smiles>Cc1c(N(C)CSO[Na])c(=O)n(-c2ccccc2)n1C</smiles>

Molecular formula $\mathrm{C}_{21} \mathrm{H}_{30} \mathrm{Br} \mathrm{N} \mathrm{O}_{4}$ Molar mass 440.4
Molecular formula $\mathrm{C}_{13} \mathrm{H}_{16} \mathrm{~N}_{3} \mathrm{Na} \mathrm{SO}_{4} \cdot \mathrm{H}_{2} \mathrm{O}$

Molar mass $\quad 351.4$

Figure (1) chemical structure of $\mathrm{HBB}$ (A) and DIP (B)

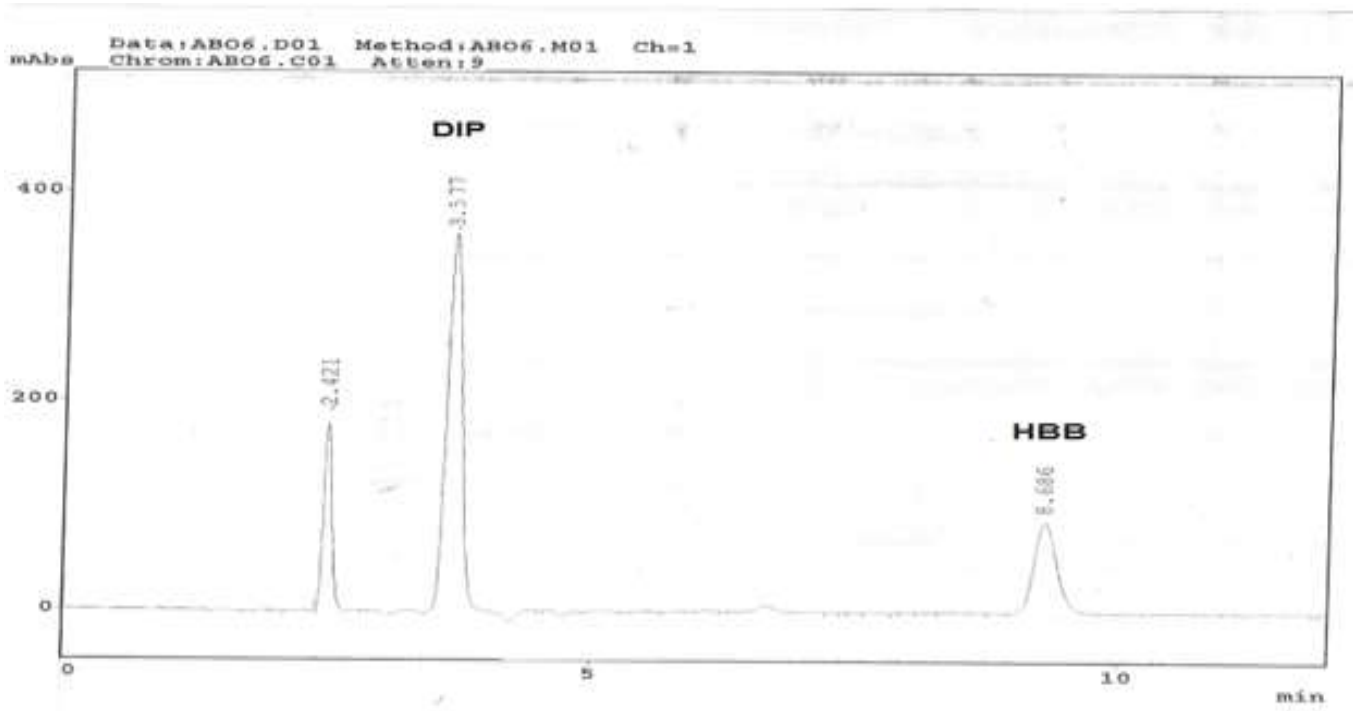

Figure (2): HPLC chromatogram showing separation of mixture of $\mathrm{HBB}$ and DIP $50 \mu \mathrm{g} \mathrm{mL} \mathrm{m}^{-1}$ of each. 


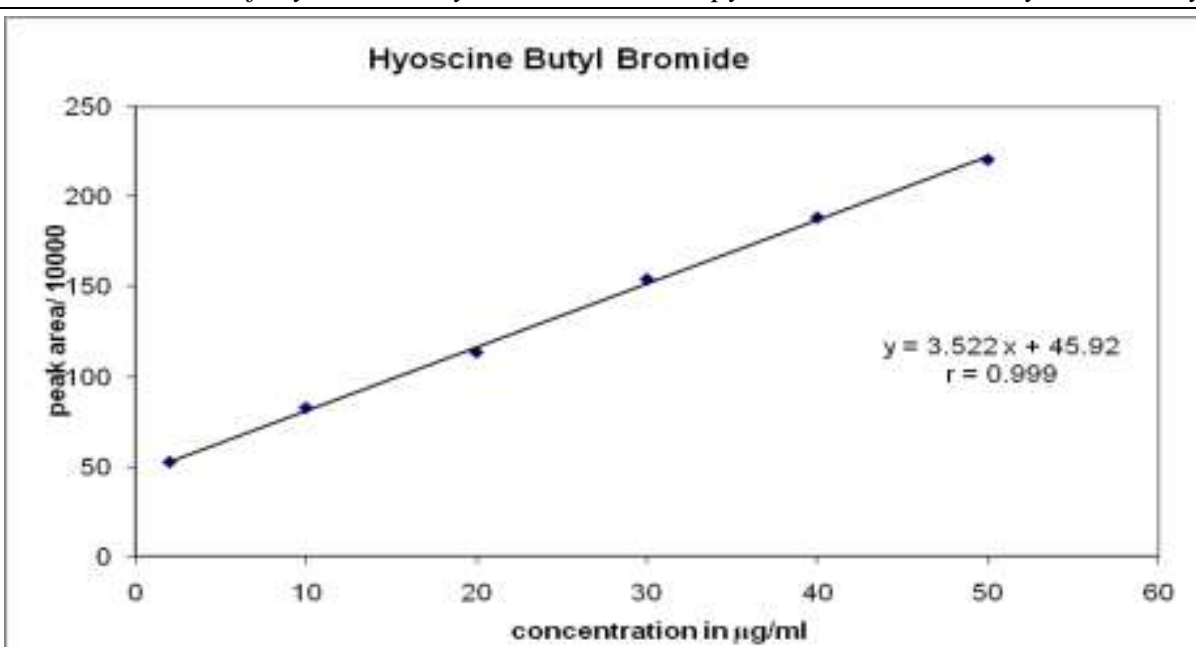

Figure (3): Linearity of the peak area at $210 \mathrm{~nm}$ to the corresponding concentration of $\mathrm{HBB}\left(2-50 \mu \mathrm{g} \mathrm{mL}{ }^{-1}\right)$ using HPLC method .

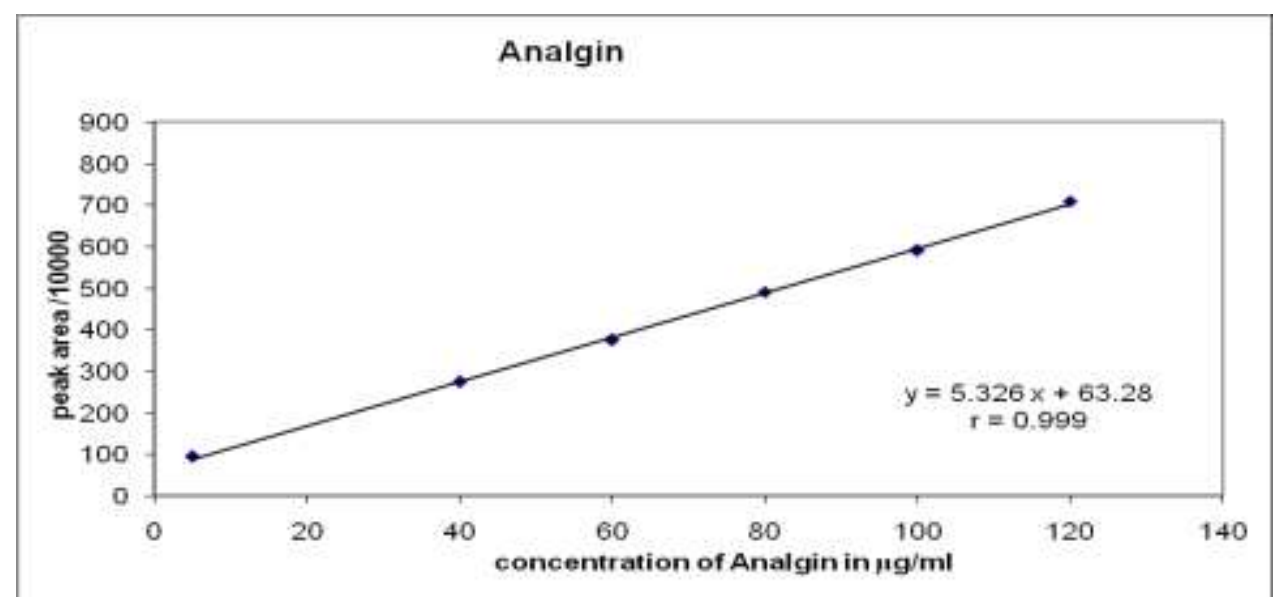

Figure (4): Linearity of the peak area to the corresponding concentration of DIP $\left(5-120 \mu \mathrm{gL} \mathrm{m}^{-1}\right)$ using HPLC method.

Table (1): Results of accuracy for determination of pure authentic of HBB and DIP by the proposed RP-HPLC method.

\begin{tabular}{|c|c|c|c|c|c|}
\hline \multicolumn{3}{|c|}{ HBB } & \multicolumn{3}{|c|}{ DIP } \\
\hline $\begin{array}{c}\text { Taken } \\
\left(\begin{array}{c}\mu \mathrm{g} . \mathrm{mL}^{-} \\
\left.{ }^{\prime}\right)\end{array}\right.\end{array}$ & $\begin{array}{l}\text { Found }^{*} \\
\left(\begin{array}{c}\mu \mathrm{g} \cdot \mathrm{mL} \\
\left.{ }_{1}\right)\end{array}\right.\end{array}$ & $\begin{array}{c}\text { Recovery } \\
\%\end{array}$ & $\begin{array}{l}\text { Taken } \\
\left(\begin{array}{c}\mu \mathrm{g} . \mathrm{mL}^{-} \\
\left.{ }_{1}\right)\end{array}\right.\end{array}$ & $\begin{array}{l}\text { Found }^{*} \\
\left(\mu \underset{{ }_{1}}{ }{ }^{\prime} \mathrm{mL}^{-}\right.\end{array}$ & $\begin{array}{c}\text { Recovery } \\
\%\end{array}$ \\
\hline 2.00 & 2.01 & 100.50 & 5.00 & 4.98 & 99.60 \\
\hline 10.00 & 10.02 & 100.20 & 10.00 & 10.05 & 100.50 \\
\hline 20.00 & 19.96 & 99.80 & 50.00 & 49.97 & 99.94 \\
\hline 30.00 & 29.95 & 99.83 & 100.00 & 100.12 & 100.12 \\
\hline 40.00 & 40.50 & 101.25 & 110.00 & 110.04 & 100.04 \\
\hline 50.00 & 49.98 & 99.96 & 120.00 & 119.10 & 99.25 \\
\hline \multicolumn{2}{|c|}{$\begin{array}{l}\text { Mean } \\
\pm \text { SD }\end{array}$} & $\begin{array}{c}100.26 \pm \\
0.552\end{array}$ & & & $\begin{array}{c}99.91 \pm \\
0.434\end{array}$ \\
\hline
\end{tabular}

* Average of three determinations 


\begin{tabular}{|c|c|c|c|c|c|c|c|}
\hline \multirow{2}{*}{$\begin{array}{l}\text { Mix. } \\
\text { No. }\end{array}$} & \multirow{2}{*}{$\begin{array}{c}\text { Ratio } \\
\text { HBB:DIP }\end{array}$} & \multicolumn{3}{|c|}{ HBB } & \multicolumn{3}{|c|}{ DIP } \\
\hline & & $\begin{array}{c}\text { Taken } \\
(\mu \mathrm{g} . \\
\text { band } \\
)\end{array}$ & $\begin{array}{c}\text { Found }^{*} \\
\left(\begin{array}{c}\mu \mathrm{g} \cdot \text { band } \\
1)\end{array}\right.\end{array}$ & $\begin{array}{c}\text { Recovery } \\
\%\end{array}$ & $\begin{array}{c}\text { Taken } \\
(\mu \mathrm{g} . \\
\left.\text { band }^{-1}\right)\end{array}$ & $\begin{array}{l}\text { Found } \\
(\mu g . \\
\left.\text { band }^{-1}\right)\end{array}$ & $\begin{array}{c}\text { Recovery } \\
\%\end{array}$ \\
\hline 1 & $1: 1$ & 10.00 & 9.99 & 99.90 & 10.00 & 10.03 & 100.30 \\
\hline 2 & $1: 2$ & 10.00 & 10.12 & 101.20 & 20.00 & 19.96 & 99.80 \\
\hline 3 & $1: 5$ & 10.00 & 10.05 & 100.50 & 50.00 & 50.05 & 100.10 \\
\hline 4 & $1: 10$ & 2.00 & 2.00 & 100.00 & 20.00 & 20.05 & 100.25 \\
\hline 5 & 1: $25^{* * *}$ & 2.00 & 2.02 & 101.00 & 50.00 & 49.85 & 99.70 \\
\hline 6 & $1: 125^{* * * *}$ & $\begin{array}{l}2.00 \\
0.96\end{array}$ & 1.98 & 99.00 & $\begin{array}{l}250.00 \\
120.00\end{array}$ & 122.00 & 101.67 \\
\hline $\begin{array}{l}\text { Mean } \\
\pm \mathrm{SD}\end{array}$ & & & & $\begin{array}{l}100.27 \\
\pm 0.809\end{array}$ & & & $\begin{array}{l}100.30 \\
\pm 0.711\end{array}$ \\
\hline
\end{tabular}

Table (2): Determination of HBB and DIP in laboratory prepared mixtures by the proposed RP-

HPLC method.

- Average of three determinations

** The ratio present in Buscopan compositium tablets.

**** The ratio present in Buscopan compositium ampoules.

Table (3): Application of standard addition technique to analysis of HBB and DIP in dosage forms by the RPHPLC method.

\begin{tabular}{|c|c|c|c|c|c|c|c|c|}
\hline Dosage form & Drug & $\begin{array}{l}\text { Taken } \\
\left(\mu \mathrm{g} \cdot \mathrm{mL}^{-1}\right)\end{array}$ & $\begin{array}{l}\text { Found* } \\
\left(\mu \mathrm{g} \cdot \mathrm{mL}^{-1}\right)\end{array}$ & Found \% & $\begin{array}{l}\text { Pure } \\
\text { added } \\
\left(\mu \mathrm{g} \cdot \mathrm{mL}^{-1}\right)\end{array}$ & $\begin{array}{l}\text { Pure } \\
\text { Found } \\
\left(\mu \mathrm{g} \cdot \mathrm{mL}^{-1}\right)\end{array}$ & $\begin{array}{l}\text { Recovery } \\
\%\end{array}$ & $\begin{array}{l}\text { Mean } \\
\pm \text { SD }\end{array}$ \\
\hline \multirow{2}{*}{$\begin{array}{l}\text { Buscopan } \\
\text { compositum } \\
{ }^{\circledR} \text { tablets } \\
\text { Batch No } \\
115815 \mathrm{~T}\end{array}$} & HBB & 2.00 & 1.98 & 99.00 & $\begin{array}{l}2.00 \\
4.00 \\
6.00\end{array}$ & $\begin{array}{l}2.04 \\
4.01 \\
6.04\end{array}$ & $\begin{array}{l}102.00 \\
100.25 \\
100.67\end{array}$ & $\begin{array}{l}100.97 \pm \\
0.914\end{array}$ \\
\hline & DIP & 5.00 & 5.02 & 100.40 & $\begin{array}{l}5.00 \\
10.00 \\
15.00\end{array}$ & $\begin{array}{l}5.00 \\
10.05 \\
15.15\end{array}$ & $\begin{array}{l}100.00 \\
100.50 \\
101.00\end{array}$ & $\begin{array}{l}100.50 \pm \\
0.500\end{array}$ \\
\hline \multirow{2}{*}{$\begin{array}{l}\text { Buscopan } \\
\text { compositum }{ }^{\circledR} \\
\text { ampoules } \\
\text { Batch No } \\
116551 \mathrm{~A}\end{array}$} & HBB & 2.00 & 1.99 & 99.50 & $\begin{array}{l}2.00 \\
4.00 \\
6.00\end{array}$ & $\begin{array}{l}2.05 \\
4.04 \\
5.91\end{array}$ & $\begin{array}{l}102.50 \\
101.00 \\
98.50\end{array}$ & $\begin{array}{l}100.67 \pm \\
2.021\end{array}$ \\
\hline & DIP & 5.00 & 5.04 & 100.80 & $\begin{array}{l}5.00 \\
10.00 \\
15.00 \\
\end{array}$ & $\begin{array}{l}5.05 \\
10.09 \\
15.10 \\
\end{array}$ & $\begin{array}{l}101.00 \\
100.90 \\
100.67 \\
\end{array}$ & $\begin{array}{l}100.86 \pm \\
0.171\end{array}$ \\
\hline
\end{tabular}

Average of six determinations

** Average of three determinations

Table (4): Results of assay validation parameters of the proposed RP-HPLC method for the determination of HBB and DIP in binary mixture.

\begin{tabular}{|c|c|c|}
\hline Parameters & HBB & DIP \\
\hline Range $\left(\mu \mathrm{g} \cdot \mathrm{mL}^{-1}\right)$ & $\begin{array}{c}2-50 \\
\left(\mu \mathrm{g} . \mathrm{mL}^{-1)}\right.\end{array}$ & $\begin{array}{c}5-120 \\
\left(\mu \mathrm{g} \cdot \mathrm{mL}^{-1)}\right.\end{array}$ \\
\hline Slope & 3.522 & 5.326 \\
\hline Intercept & 45.92 & 63.28 \\
\hline Correlation coefficient $(\mathrm{r})$ & 0.9997 & 0.9996 \\
\hline $\begin{array}{c}\text { Accuracy } \\
(\text { mean } \pm \text { SD) }\end{array}$ & $100.26 \pm 0.552$ & $99.91 \pm 0.434$ \\
\hline$(\mathrm{RSD} \%)^{\mathrm{a}} *$ & 0.973 & 0.721 \\
\hline$(\mathrm{RSD} \%)^{\mathrm{b}}$ & 0.753 & 0.688 \\
\hline
\end{tabular}

$(\mathrm{RSD} \%)^{\mathrm{a} *},(\mathrm{RSD} \%)^{\mathrm{b}} *$ the intra-day and inter-day relative standard deviations of the average of concentrations $\left(20,40\right.$ and $50 \mu \mathrm{g} \cdot \mathrm{mL}^{-1}$ for each). 
Table (5): Statistical analysis of parameters required for system suitability testing of the proposed RP-HPLC method.

\begin{tabular}{|c|c|c|c|}
\hline \multirow[t]{3}{*}{ Parameters } & \multicolumn{3}{|c|}{ For RP-HPLC method } \\
\hline & \multicolumn{2}{|c|}{ Obtained value } & \multirow[t]{2}{*}{ Reference value } \\
\hline & HBB & DIP & \\
\hline Resolution $\left(\mathrm{R}_{\mathrm{s}}\right)$ & \multicolumn{2}{|c|}{11.36} & $>1.5$ \\
\hline Capacity factor(K') & 2.59 & 0.48 & 1- 10 acceptable \\
\hline Tailing factor $(\mathrm{T})$ & 1.17 & 1.00 & $<1.5-2$ \\
\hline Selectivity factor $(\gamma)$ & \multicolumn{2}{|c|}{5.40} & $>1$ \\
\hline $\begin{array}{c}\text { Number of Theoretical } \\
\text { plate }(\mathrm{N})\end{array}$ & 48219136 & 12744900 & Increases with increases efficiency \\
\hline $\begin{array}{c}\text { HETP } \\
\left(\mathrm{cm} \cdot \text { plate }^{-1}\right) \\
\begin{array}{c}\text { Height equivalent to } \\
\text { theoretical plate }\end{array}\end{array}$ & 0.0518 & 0.1962 & $\begin{array}{l}\text { The smaller the value, the higher the } \\
\text { efficiency }\end{array}$ \\
\hline
\end{tabular}

Table (6): Statistical analysis of the results obtained by proposed RP-HPLC method and reference method for the determination of HBB and DIP.

\begin{tabular}{|c|c|c|c|c|}
\hline \multirow{2}{*}{ Parameter } & \multicolumn{2}{|c|}{$\begin{array}{c}\text { RP-HPLC } \\
\text { method }\end{array}$} & \multicolumn{2}{|c|}{$\begin{array}{c}\text { Reference } \\
\text { method }\end{array}$} \\
\cline { 2 - 5 } & HBB & DIP & HBB & DIP \\
\hline Mean \% & 100.26 & 99.91 & 99.21 & 100.22 \\
\hline SD & 0.552 & 0.434 & 1.012 & 0.544 \\
\hline $\mathrm{n}$ & 6 & 6 & 6 & 6 \\
\hline $\begin{array}{c}\text { Student 's } \\
\text { t-test (2.23) }\end{array}$ & 0.061 & 0.304 & & \\
\hline $\begin{array}{c}\text { F-value } \\
(5.05)^{\mathrm{b}}\end{array}$ & 3.361 & 1.571 & & \\
\hline
\end{tabular}

a manufactured method personal communications

$\mathrm{b}$ the values between parenthesis are the theoretical values for $\mathrm{t}$ and $\mathrm{F}$ at $\mathrm{P}=0.05$

\section{References}

[1] Martindale" The Extra Pharmacopoeia", $31^{\text {st }}$ Ed., Pharmaceutical press London, (2007)

[2] Mohamed, F. A.; AbdAllah, M. A.; Shammat, S. M.: Selective spectrophotometric determination of p-aminophenol and acetaminophen. Talanta 1997, 44(3), 61-68.

[3] Mahrous, M.; Daabees, H.; Beltagy, Y., New sensitive method for the analysis of some non uv absorbing quaternised compounds Spectroscopy letters 1992, 25 (3), 389-400.

[4] Issopoulos, P.; Pavlou-Zervou, E., Application of ion pair complexes of some acid-base indicators in pharmaceutical analysis. I: Spectrophotometric microdetermination of L-hyoscine butyl bromide by its ion pair complex with methyl organge. Il Farmaco 1994, 49 (3), 205-210.

[5] Thomos, K. M.; Dabholkar, D. A.; Jain, C. L., Spectrophotometric determination of hyoscine butyl bromide in pharmaceutical formulations. Indian Drugs 1994, 31 (8), 391-392.

[6] Dinē, E.; Onur, F., Application of a new spectrophotometric method for the analysis of a ternary mixture containing metamizol, paracetamol and caffeine in tablets. Analytica chimica acta 1998, 359 (1-2), 93-106.

[7] Papadoyannis, I.; Zotou, A.; Samanidou, V.; Georgarakis, M., Solid-phase extraction and RP-HPLC analysis of atropine sulphate and scopolamine-N-butylbromide in pharmaceutical preparations and biological fluids. Instrumentation science \& technology 1994, 22 (1), 83-103.

[8] Asmardi, G.; Jamali, F., High-performance liquid chromatography of dipyrone and its active metabolite in biological fluids. Journal of Chromatography B: Biomedical Sciences and Applications 1983, 277, 183-189.

[9] Favreto, W. A. J.; Pugens Pinto, A. M.; Manfio, J. L.; Fiametti, K. G.; Percio, M. F.; Santos, M. B. d., Development and validation of a UPLC-ESI-MS/MS method for the determination of N-butylscopolamine in human plasma: Application to a bioequivalence study. Drug Testing and Analysis 2012, 4 (3-4), 215-221.

[10] El-Saharty, Y.; Metwaly, F.; Refaat, M.; El-Khateeb, S., Development of membrane electrodes for the selective determination of hyoscine butylbromide. Talanta 2007, $72(2), 675-681$.

[11] Farhadi, K.; Karimpour, A., Electrochemical behavior and determination of hyoscine-N-butylbromide from pharmaceutical preparations. JOURNAL-CHINESE CHEMICAL SOCIETY TAIPEI 2007, 54 (1), 165.

[12] Teixeira, M. F. S.; Marcolino-Junior, L. H.; Fatibello-Filho, O.; Moraes, F. C.; Nunes, R. S., Determination of analgesics (dipyrone and acetaminophen) in pharmaceutical preparations by cyclic voltammetry at a copper (ii) hexacyanoferrate (iii) modified carbon paste electrode. Current Analytical Chemistry 2009, 5 (4), 303.

[13] Wassel, A. A.; Abu-Talib, N., Sensors membrane electrodes for sensitive determination of hyoscine butylbromide in pharmaceutical formulation and in human plasma. Journal of Sensing in electroanalysis. K. Vytřas, K. Kalcher, I. Švancara (Eds.). 2010, Volume 5 . 
[14] Cherkaoui, S.; Mateus, L.; Christen, P.; Veuthey, J.-L., Nonaqueous versus aqueous capillary electrophoresis for the dosage of Nbutylscopolamine in various pharmaceutical formulations. Journal of pharmaceutical and biomedical analysis 1999, 21 (1), 165174.

[15] Chang, Y. S.; Ku, Y. R.; Wen, K. C.; Ho, L. K., ANALYSIS OF SYNTHETIC GASTROINTESTINAL DRUGS IN ADULTERATED TRADITIONAL CHINESE MEDICINES BY HPCE. Journal of Liquid Chromatography \& Related Technologies 2000, 23 (13), 2009-2019.

[16] "The British Pharmacopoeia", British Pharmacopoeia Commision, London 2009.

[17] El-Zeany, B. A.; Amer, M. M.; Taha, A. M.; El-Sawy, O. A., Determination of organic pharmaceuticals with Nbromosuccinimide. Part III. Some pyrazolone derivatives by direct titration. Analyst 1982, 107 (1278), 1054-1059.

[18] Amer, M. M.; El-Zeany, B. A ;.Taha, A. M.; El-Sawy, O. A., Determination of organic pharmaceuticals with Nbromosuccinimide. Part IV. Some pyrazolone derivatives by back-titration. Analyst 1982, 107 (1279), 1272-1278.

[19] Erk, N.; Onur, F., Spectrophotometric simultaneous determination of analgin and hyoscine n-butyl bromide in sugar-coated tablets. Analytical Letters 1996, 29 (3), 369-380.

[20] ICH Harmonized Tripartite Guideline: Validation of Analytical Procedures: Text and Methodology, Q2(R1)Geneva, 2005. 